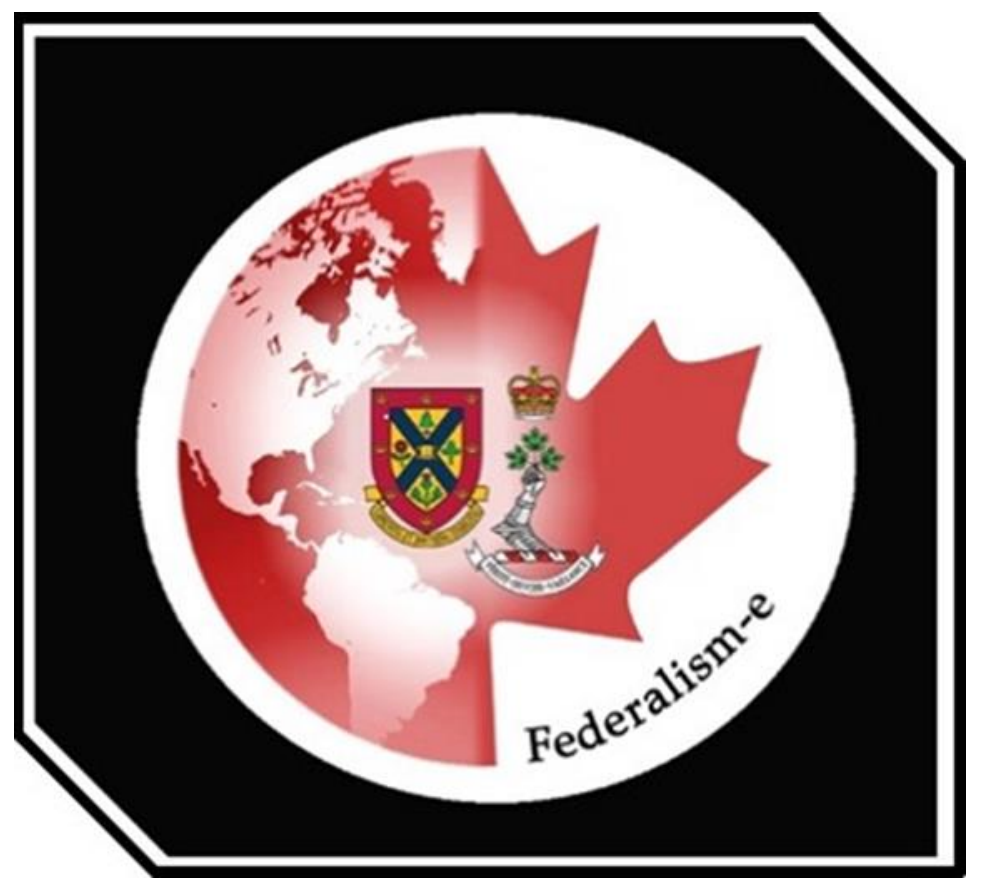

\title{
Federalism-E
}

\section{Oklahoma City Bombing -}

\section{A Story Marked by Resilience in the Face of Tragedy, Yet Indicative of the Broader Homeland Security Challenges Diverse Republics Must Confront}

By: Megan Bryn Gephart

United States Military Academy

Federalism-E is founded by the Royal Military College of Canada and the Institute of Intergovernmental Relations at Queen's University 
Federalism- $E$ is an online, undergraduate student-run journal focusing on the theory of federalism. Federalism-E publishes academic articles and essays focusing on federalism, multi-level governance, and intergovernmental relations. Publishing in both English and French, the journal has a mandate to provide a forum encouraging research and scholarly debate with respect to a wide variety of issues concerning federalism, both within Canada and abroad.

\section{Editors-in-Chief}

Officer Cadet Miles Smith, Royal Military College of Canada

Officer Cadet Alexandre Veilleux, Royal Military College of Canada

\section{Associate Editors:}

Officer Cadet Jack Wery, Royal Military College of Canada

Officer Cadet Jack Murphy, Royal Military College of Canada

Officer Cadet Damian McCracken, Royal Military College of Canada

Rylee Rose Kloek, University of Ottawa

Joyce Le-Yi Yang, University of Toronto

Mduduzi Mhlanga, University of Toronto

Srijan Sahu, University of Toronto

Jenna Mohammed, University of Toronto Mississauga

Ali Bachir Taha, University of Toronto

Charmaine Lee, University of British Columbia

Faculty Advisor:

Dr. Christian Leuprecht, Royal Military College of Canada, Institute of Intergovernmental

Relations at Queen's University

Contact Information:

Address: Royal Military College of Canada

13 General Crerar Crescent

Kingston

ON, K7K 7B4

ISSN: 2562-3435

Email: federalismeditors@gmail.com

Website: https://ojs.library.queensu.ca/index.php/fede

Federalism-E is founded by the Royal Military College of Canada and the Institute of Intergovernmental Relations at Queen's University 
The 1995 Oklahoma City bombing, the deadliest terrorist attack in the United States prior to September 11 $1^{\text {th }}, 2001$, provides valuable insights into many of the key homeland security challenges faced by a diverse Republic like the United States. These tactical, operational, and strategic-level challenges include but are not limited to: communication; operations and logistics; victim and family support; public perception, media, and information dissemination; the tensions between liberty and security in law and policymaking; and the relationship between the executive and legislative branches and their roles and tendencies during and after a national security crisis. Although the aftermath was marked by some noteworthy successes and resilience in the face of great tragedy, this article analyzes the effectiveness of the tiered, progressive emergency response, particularly highlighting shortcomings, broader implications, and impacts for the U.S. and other republics in their approach to dealing with terrorism and homeland security incidents moving forward.

\section{Introduction}

On the morning of April 19, 1995, an anti-government extremist drove a truck of homemade explosives into the nine-story Alfred P. Murrah Federal Building in Oklahoma City, an act that forever changed perceptions about the safety of American society and the security risks U.S. citizens and federal employees face. ${ }^{1}$ Timothy McVeigh, the perpetrator of this deadliest terrorist attack in the United States to date, killed 168 people, wounded 674 more, and damaged twentyfive nearby buildings. ${ }^{2}$ In the wake of this devastating event, the nation came together to respond at all levels, confronting many challenges but also learning difficult lessons along the way. As U.S. Senator Richard Shelby emphasized in his opening remarks in a special hearing before the Senate's Appropriations Committee, this attack "shook our [nation's] faith in the fundamental safety of civil society, and [left the nation] feeling less secure in our homes and workplaces."3 Although he acknowledged that this act of violence may not have been preventable, he also stated that "this tragedy has, and I believe rightly, compelled us to rethink some fundamental assumptions about our domestic security," and offers opportunities to learn more about how we can better address the threat of terrorism while preserving our openness and freedom. ${ }^{4}$ Despite a

${ }^{1}$ Gabriel Rubin, 2008, "Balancing Fear: Why Counter-Terror Legislation was Blocked after the Oklahoma City and London Bombings." Conference Papers -- Midwestern Political Science Association 1-38. Political Science Complete, EBSCOhost (accessed May 8, 2018), and 1996. Oklahoma City bombing: hearing before a subcommittee of the Committee on Appropriations, United States Senate, One Hundred Fourth Congress, first session: special hearing. n.p: Washington: U.S. G.P.O.: For sale by the U.S. G.P.O., Supt. of Docs., Congressional Sales Office, 1996., 1996. USMA Library Catalog, EBSCOhost (accessed May 8, 2018). 36.

${ }^{2}$ Ibid.

3 1996. Oklahoma City bombing: hearing before a subcommittee of the Committee on Appropriations, United States Senate, One Hundred Fourth Congress, first session: special hearing. n.p: Washington: U.S. G.P.O.: For sale by the U.S. G.P.O., Supt. of Docs., Congressional Sales Office, 1996., 1996. USMA Library Catalog, EBSCOhost (accessed May 8, 2018). 1.

${ }^{4}$ Ibid, 2. 
holistically successful response, this case provides valuable insights into many of the key homeland security challenges faced by a diverse Republic like the United States, including but not limited to: intergovernmental and multi-organizational communication; operations and logistics; victim and family support; public perception, media, and information dissemination; the tensions between liberty and security in law and policymaking; and the relationship between the executive and legislative branches and their roles and tendencies during and after a national security crisis.

\section{Federalism in Action: Tiered Emergency Management}

The Oklahoma City bombing incident offers insight into how the United States functions in terms of disaster response. Immediately following the massive explosion, a series of actions were taken at each level, from local emergency and first responder teams, to the federal government and President of the United States. Within the U.S., domestic emergency management doctrine is based on a tiered, bottom-up framework that begins at the local level and is progressively supported by higher-level response capabilities when needed. ${ }^{5}$ This approach maximizes efficiency and encourages community resiliency and self-sufficiency at the local level. For emergencies that are larger in scope and scale, first responders, which are typically at the lowest level in a republic and federal system, set the tone and retain control of the response effort even when resources are overwhelmed, and state or federal assistance is required.

To provide an understanding of the scope of the damage and role the different levels of government played in terms of monetary value, The State Office of Civil Emergency Management requested a reimbursement of \$3 million for Oklahoma City and other departments and organizations that contributed in the aftermath. Within a year, over \$2.8 million was distributed across the various cities and counties that had responded. ${ }^{6}$ An estimate of the total costs incurred by the bombing included $\$ 426,594,000$ in non-federal losses (i.e. losses to buildings and property, medical services, lost income, sales and taxes) and \$225,000,000 in federal losses. $\$ 164,046,000$ were estimated to come from state and local relief programs and insurance, which offer the first sources of major funding. Federal Emergency Management Agency (FEMA) and non-FEMA federal programs, businesses, individuals, and charities were expected to cover the remainder. Furthermore, the Oklahoma City bombing was the first incident that simultaneously constituted a federal disaster and a crime scene. This significantly impacted the total costs; the federal government spent $\$ 82.5$ million dollars investigating the bombing and trying the perpetrator Timothy McVeigh and Terry Nichols, his accomplice. An indication of the substantial cost of justice, the defense of McVeigh cost \$15 million and the defense of Nichols cost \$6.3 million in U.S. taxpayer dollars. Nichols was later tried in a state case to ensure accountability for the other 160 victims beyond the eight federal agents killed, with his defense costing $\$ 4.12$ million. $^{7}$

\footnotetext{
${ }^{5}$ Jeffrey W. Burkett, "Command and Control of Military Forces in the Homeland," Joint Force Quarterly no 51, (4 ${ }^{\text {th }}$ Quarter 2008): 132.

${ }^{6}$ Oklahoma City National Memorial Museum, "Recovery: The Financial Impact of the Oklahoma City Bombing," 1, Available from: https://oklahomacitynationalmemorial.org/wpcontent/uploads/2018/03/OKCNM_Recovery-The-Financial-Impact.pdf.

${ }^{7}$ Ibid., 4.
} 


\section{$\underline{\text { Local Level }}$}

As the mayor and City Council's report states, "The Murrah Building became the focus of a rescue and recovery effort that began on April $19^{\text {th }}$ and ended on May $4^{\text {th }}$. The chaos of the first hours gave way to a determined, disciplined effort." ${ }^{\text {"I }}$ spite of communications simultaneously faltering due to the blast, seven emergency medical service units responded within minutes. ${ }^{9}$ With 350 people in the building at the time of the bombing, the Oklahoma City Fire Department mounted a massive search and rescue effort and immediately created an Incident Command System. An Incident Command System is a standardized organizational management system designed to establish a common hierarchy structure and integrate multiple agencies to enable effective and efficient responses to emergencies. ${ }^{10}$ These units as well as fire, emergency medical, law enforcement personnel, voluntary organization workers, and many civilians contributed in the crucial moments following the blast, clearing passages and beginning to triage the large number of victims in critical condition. Officials established a controlled perimeter and ensured no more explosives remained.

\section{State Level}

As state and higher-level actors began to mobilize, the fire department and the command system managed the influx of federal, state, local, and voluntary agency response personnel and equipment. Soon the Oklahoma Department of Civil Emergency Management (ODCEM) and State Emergency Operations Center (SEOC) initiated 24-hour operations to coordinate assistance from state agencies in the realms of public safety, human services, military (National Guard and others), health and medical, education, and weather. The Oklahoma Department of Civil Emergency Management serves as Oklahoma's liaison with federal and local agencies, preparing for, responding to, recovering from, and mitigating against disasters and emergencies. ${ }^{11}$ Its director reports directly to the Governor (the state's chief executive officer and commander-inchief) and maintains, updates, and exercises the State Emergency Operations Center and State Emergency Operations plan, as well as aids and provides funds to more than 400 local emergency management departments throughout Oklahoma. State Emergency Operations Centers are intended to serve as command centers and facilitate close and effective coordination between state agencies as they carry out their own responsibilities and activities in responding to emergencies. ${ }^{12}$ This SEOC was fully operational by 9:25 a.m., 23 minutes after the attack. ${ }^{13}$ By

\footnotetext{
${ }^{8}$ City of Oklahoma City Final Report-Alfred P. Murrah Federal Building Bombing, April 19, 1995 (Fire Protection Publications: Stillwater, OK,1996), 5.

${ }^{9}$ Ibid.

${ }^{10}$ FEMA, "Incident Command System Resources," U.S. Department of Homeland Security, Last modified June 26, 2018, Accessed February 27, 2019, https://www.fema.gov/incidentcommand-system-resources.

${ }^{11}$ Oklahoma Department of Emergency Management, "About OEM,” Oklahoma.gov, Last Modified 2019, Accessed February 27, 2019, https://www.ok.gov/OEM/About_OEM/index.html.

${ }^{12}$ Homeland Security and Emergency Management, "About the SEOC," Minnesota Department of Public Safety, Last modified 2019, Accessed February 27, 2019, https://dps.mn.gov/divisions/hsem/seoc/Pages/about-seoc.aspx.

${ }^{13}$ City of Oklahoma City Final Report_-Alfred P. Murrah Federal Building Bombing, April 19, 1995 (Fire Protection Publications: Stillwater, OK,1996), 6.
} 
9:45 a.m., Oklahoma Governor Frank Keating ordered a "State of Emergency." He and Lieutenant-Governor Mary Fallin arrived at the SEOC and received a situation briefing from the ODCEM Director at 10:05 a.m., and over the course of the day the Governor commanded between the SEOC and site of the attack.

\section{Regional and Federal Levels}

When the incident was reported to the Federal Emergency Management Agency (FEMA), the Regional Director followed suit by activating the Regional Operations Center, the counterpart to the SEOC at the regional, federal level. FEMA headquarters received its briefing in Washington D.C. by 10:35 a.m., then immediately alerted its Urban Search and Rescue Task Forces from Phoenix, Arizona and Sacramento, California that they would soon deploy to Oklahoma City. ${ }^{14}$ They arrived by 11:00 p.m. and 11 teams received on-site briefings from the commanders on the ground, assessed the overall situation, and began their work. ${ }^{15}$

At the national level, U.S. President Bill Clinton signed Emergency Declaration FEMA3113-EM-OK at 4:00 p.m., enabling the federal government to supplement the local and state agencies with further emergency assistance with the intent of "saving lives, protecting property, public health and safety, and lessening or averting the threat of further damage."16 This empowered lower level organizations and entities to conduct key tasks and authorized reimbursement for all eligible response missions of the state and local government. Interestingly, FEMA relaxed the regulations that implement the Stafford $\mathrm{Act}^{17}$ which allowed for a more effective response because it provided greater flexibility to the state and local governments to distribute assistance as they saw fit, even though the President issued an "Emergency Declaration" rather than a "Major Disaster Declaration."18 About a week later, the President granted the Governor's request for a Major Disaster Declaration in order to be eligible to receive federal assistance with long-term recovery and restoration programs along with the Emergency

${ }^{14}$ Ibid., 7.

15 Ibid., 12.

16 Ibid.

17 “The Robert T. Stafford Disaster Relief and Emergency Assistance Act (the Stafford Act) authorizes the President to issue two types of declarations that could potentially provide federal assistance to states and localities in response to a terrorist attack: a "major disaster declaration" or an "emergency declaration." Major disaster declarations authorize a wide range of federal assistance to states, local governments, tribal nations, individuals and households, and certain nonprofit organizations to recover from a catastrophic event. Emergency declarations authorize a more limited range of federal assistance to protect property and public health and safety, and to lessen or avert the threat of a major disaster. Only private nonprofit organizations are eligible for disaster loans under an emergency declaration." U.S. Congressional Research Service, 2019, "Stafford Act Assistance and Acts of Terrorism," R44801, Available from: https://fas.org/sgp/crs/homesec/R44801.pdf.

${ }^{18}$ Moss, Mitchell \& Schellhamer, Charles \& A. Berman, David, (2009), The Stafford Act and Priorities for Reform, Journal of Homeland Security and Emergency Management - J HOMEL SECUR EMERG MANAG. 6. 10.2202/1547-7355.1538. See also Roberts, Patrick, "FEMA After Katrina,” Hoover Institution Policy Review \#137, Online. 
Declaration funds dedicated to direct response efforts. ${ }^{19}$ Both the Governor and President received situation reports daily - another indication of the leadership dynamics and relationship between the local, state, and federal levels.

The structure and coordination mechanisms evolved throughout the response and recovery phases; however, the on-the-ground chain of command remained the same with the city's fire department controlling the 17-day search and rescue effort, and the Federal Bureau of Investigation (FBI) conducting the investigative mission for the crime. Although the federal government had the authority to lead the search and rescue mission, it allowed the Oklahoma City Fire Department to maintain command. ${ }^{20}$ This authority framework introduced some challenges as the FBI had to search for evidence while the search and rescue team cleared through debris. The FBI thus built a new protocol to prioritize and help de-conflict between the simultaneous lines of effort: 1 . Locate any survivors; 2 . Remove any victims; 3 . Process the crime scene." $" 11$

\section{Effectiveness of the Response}

The last survivor of the blast was pulled from the rubble at 10:05 p.m. on the day of the attack. Yet, as a testament to the character of those who served, determination and motivation remained high for the 16 days of search and rescue to follow. ${ }^{22}$ Generally, the public viewed the response and recovery efforts as an overall success, and thousands of individuals from all levels and sectors contributed to the lasting legacies of courage and resilience in the aftermath of such tragedy. As the City of Oklahoma City's Final Report on the bombing states, "There is no doubt that the response [and] recovery missions achieved by federal, state, local and voluntary organizations, pursuant to the bombing, should and will be viewed as a successful operation. However, if the knowledge and experience gained from this disaster remains docile in the minds of those involved, the probability of future successful operations will not increase."23 Overall, in spite of the general effectiveness of the response, this case and its lessons learned expose key tactical, operational, and strategic-level challenges faced by the homeland security enterprise within a diverse republic like the United States.

\section{Noteworthy Successes}

\section{Federalism Framework: Roles, Responsibilities, Authorities, and Resources}

Oklahoma City's Final Report on the bombing cites several main reasons the operation ran smoothly overall. The jurisdiction's abundance of emergency resources and strong state and federal government presence were instrumental in facilitating unparalleled cooperation between

${ }^{19}$ Oklahoma City National Memorial Museum, "Recovery: The Financial Impact of the Oklahoma City Bombing," 1, Available from: https://oklahomacitynationalmemorial.org/wpcontent/uploads/2018/03/OKCNM_Recovery-The-Financial-Impact.pdf.

${ }^{20}$ Ibid.

${ }^{21}$ City of Oklahoma City Final Report—Alfred P. Murrah Federal Building Bombing, April 19, 1995 (Fire Protection Publications: Stillwater, OK,1996), 13.

${ }^{22}$ Ibid., 16.

${ }^{23}$ Ibid. 
the local, state, and federal levels. In terms of first responders, an impressive number of ambulance services, units, and emergency medical personnel contributed and stayed to assist the immediate response from fire, police, emergency medical, and military personnel was phenomenal, drawing from Oklahoma City Fire Department's total force of 1,010 men and women, the Police Department's 995 sworn personnel, 302 civilian personnel, and 43 recruits in training among others. ${ }^{24}$ At the federal level, the Treasury Department dispatched all its available resources to assist local authorities and actors, support the people who remained, guarantee facilities could continue to function, ensure investigative support and personnel began work immediately, establish any temporary facilities needed, and provide emotional support. The Treasury Department's law enforcement agencies (especially the Secret Service and Bureau of Alcohol, Tobacco, Firearms) executed a quick, thorough investigation. ${ }^{25}$ The report emphasized the role strong executive leadership and common concerns played at and between all levels, noting that many of the procedures would become a "model for the future."26

\section{Military Response}

In responding to homeland security incidents and other domestic emergencies, the military can play a significant role in assisting with disaster relief, as it did in this case. Before diving into the military's contributions after the Oklahoma City terrorist attack, I will first provide background into the authorities that govern the role and scope of military support operations within the realm of homeland security. At the state level, governors reserve the ability, under the U.S. Constitution, to call upon the National Guard in times of domestic emergencies or need. ${ }^{27}$ Largely funded by the federal government and trained according to federal standards, the National Guard is a state-based military force shared by the states and federal government and readily accessible for both purposes, a "[reflection] of the constitutional balance of power between the sovereign states and central federal government." 28 The National Guard can be employed in three ways: by the Governor for a state purpose, by the Governor with the concurrence of the President for shared state/federal purposes or for a primary federal purpose (Title 32 Duty), or by the President for a federal purpose authorized by federal law (Title 10 Duty). ${ }^{29}$ Under a Title 32 status, the Governor (as the state's commander-in-chief) and state

24 Ibid., 12.

25 1996. Oklahoma City bombing: hearing before a subcommittee of the Committee on Appropriations, United States Senate, One Hundred Fourth Congress, first session: special hearing. n.p.: Washington: U.S. G.P.O.: For sale by the U.S. G.P.O., Supt. of Docs., Congressional Sales Office, 1996., 1996. USMA Library Catalog, EBSCOhost (accessed May 8, 2018). 3, 35.

${ }^{26}$ City of Oklahoma City Final Report_-Alfred P. Murrah Federal Building Bombing, April 19, 1995 (Fire Protection Publications: Stillwater, OK,1996), 36.

${ }^{27}$ Oklahoma National Guard, “About,” Guard Advocacy Program, Accessed on February 27, 2019, https://ok.ng.mil/pages/about.aspx.

28 Timothy J. Lowenberg, "The Role of the National Guard in National Defense and Homeland Security," National Guard Association of the United States, 2.

29 1996. Oklahoma City bombing: hearing before a subcommittee of the Committee on Appropriations, United States Senate, One Hundred Fourth Congress, first session: special hearing. n.p.: Washington: U.S. G.P.O.: For sale by the U.S. G.P.O., Supt. of 
government retains operational, tactical, and administrative control over the National Guard forces. These domestic missions are intended to protect vital state interests and maximize attainment of national defense and homeland security objectives. This Constitutional basis, the Immediate Response Authority, and the Stafford Act were the key legal authorities that underpinned Military Support to Civil Authority after the Oklahoma City bombing. ${ }^{30}$ As previously mentioned, a presidential declaration can trigger federal relief through the Stafford Act, but it also authorizes the President to use the Department of Defense resources in the immediate aftermath of an incident to preserve life and property.

After Governor Frank Keating's activation, at least 731 Oklahoma Guard members assisted civilian and government response agencies in every phase of the operation following the bombing. ${ }^{31}$ Medevac aircraft, ambulances, bomb detecting dog teams, and various personnel from nearby military bases and units from across the country assisted in the minutes and days that followed. Guard members established an emergency operations center, performed lifesaving care, helped search for, identify, and transport survivors, assisted police with maintaining the security perimeter, provided equipment and airlifted supplies and donations, supported families of victims, and helped the FBI clear through debris and search for evidence. ${ }^{32}$

\section{Community Resilience}

Finally, every person involved in the response and recovery operation was personally invested and contributed to the resiliency of the community, state, and nation at large; importantly, "all were victims." 33 As evidence of the people of Oklahoma City coming together, there was a massive influx of donations of equipment and supplies from individuals and businesses of all sizes, and the smooth process by which the team secured temporary space and replacement furniture for the federal agencies that needed a new home was noteworthy.

Buildings within a couple blocks of the bombing reoccupied Monday morning, and were up and running shortly thereafter. ${ }^{34}$ Over the longer-term, the Oklahoma City community donated \$49 million to various agencies to assist the survivors, family members, and rescue workers affected by the bombing. ${ }^{35}$

Docs., Congressional Sales Office, 1996., 1996. USMA Library Catalog, EBSCOhost (accessed May 8, 2018). 3.

30 Jim Winthrop, “Oklahoma City Bombing: Immediate Response Authority and Other Military Assistance to Civil Authority," National Criminal Justice (1997): Abstract. https://s3-uswest-2.amazonaws.com/webcitation/f40c023b564c767e7ab576332e3425c6ab89a786.

${ }^{31}$ Mike R. Smith, "Guardmembers Remember Oklahoma City Bombing," U.S. Army, April 19, 2010, Accessed on February 27, 2019,

32 Ibid. https://www.army.mil/article/37587/guardmembers_remember_oklahoma_city_bombing.

${ }^{33}$ City of Oklahoma City Final Report - Alfred P. Murrah Federal Building Bombing, April 19, 1995 (Fire Protection Publications: Stillwater, OK,1996), 34.

34 Ibid., 20.

${ }^{35}$ Oklahoma City National Memorial Museum, "Recovery: The Financial Impact of the Oklahoma City Bombing," 2, Available from: https://oklahomacitynationalmemorial.org/wpcontent/uploads/2018/03/OKCNM_Recovery-The-Financial-Impact.pdf. 


\section{Key Challenges and Shortcomings}

Despite these noteworthy successes, there were several complexities that came to light in the Oklahoma City bombing case, spanning from the tactical to strategic level. These included: intergovernmental and multi-organizational communication; operations and logistics; victim and family support; public perception, media, and information dissemination; the tensions between liberty and security in law and policymaking; and the relationship between the executive and legislative branches and their roles and tendencies during and after a national security crisis.

\section{Communication and Information Systems}

First, communication and information systems were neither well-planned, nor robust enough. The explosion knocked out primary and back-up phone lines for the local ambulance service, the Emergency Medical Services Authority, which left 9-1-1 as the only accessible emergency service. ${ }^{36}$ Cell phones initially filled the communication void, but channels quickly became overwhelmed and overloaded. ${ }^{37}$ The responding personnel relied on walkie-talkies and other handheld radios until portable systems were erected near the incident site, which had its own drawbacks: concurrent transmission of multiple messages created unintelligible cross talk, a designated disaster channel was not available for the end users, and there were not enough radios to rely solely on those. Moreover, Oklahoma City Police Department switched much of their communications to a common police channel which enabled communication within their ranks. However, this isolated them from other agencies. ${ }^{38}$ It was not until later in the afternoon that leaders were able to establish an integrated communications network to connect local and statelevel police and fire personnel with off-site counterparts and federal agencies. ${ }^{39}$ At the disaster site, early response efforts relied on human couriers before this system was emplaced that resolved the major lapses in communication. These runners became crucial link within hospital between treatment and other areas. ${ }^{40}$

Additionally, the Integrated Emergency Management System requires frequent disaster planning, training, and exercising, as well as deep commitment by every level of government. A critical byproduct of constant training and joint exercises is shared understanding of the roles, bounds, and overlapping responsibilities of the various organizations. In this case, Oklahoma City did not agree with the structure of the system, and problems therefore emerged when the

${ }^{36}$ City of Oklahoma City Final Report_-Alfred P. Murrah Federal Building Bombing, April 19, 1995 (Fire Protection Publications: Stillwater, OK,1996), 5.

${ }^{37}$ Anteau, Carlene M., and Linda A. Williams, 1998, "The Oklahoma City bombing." Nursing 28, no. 3: 52-55, Academic Search Premier, EBSCOhost (accessed May 8, 2018). 54.

${ }^{38}$ City of Oklahoma City Final Report_-Alfred P. Murrah Federal Building Bombing, April 19, 1995 (Fire Protection Publications: Stillwater, OK,1996), 39.

${ }^{39}$ Catherine Manzi, Michael J. Powers, and Kristina Zetterlund, 2002, "Critical Information Flows in the Alfred P. Murrah Building Bombing: A Case Study," CBACI, Terrorism Studies Series, Special Report 3, 30, https://www.ncjrs.gov/pdffiles1/Digitization/194411NCJRS.pdf.

${ }^{40}$ Anteau, Carlene M., and Linda A. Williams, 1998, "The Oklahoma City bombing," Nursing 28, no. 3: 52-55, Academic Search Premier, EBSCOhost (accessed May 8, 2018), 54. 
local government needed state and federal support. ${ }^{41}$ The Multi-Agency Coordination Center held two very different functions depending on who was asked: a relocation center for coordination of actions and expertise, or an emergency operations center where resources and information could be gathered. ${ }^{42}$ Later on, when the mobile command posts were established, this produced confusion, unnecessary repetitiveness, delays, and fragmented information because requests and orders were not being channeled through the proper hierarchy of the Incident Command Post. ${ }^{43}$ The key takeaway is that agency standard operating procedures should outline effective communications systems and command and control structures, then periodic joint exercises should be conducted to ensure every agency can function effectively in the event of a crisis. It is far from ideal to build coordination procedures from scratch amidst the chaos in the aftermath of a disaster. ${ }^{44}$

\section{Operations and Logistics}

Operationally, there are many areas of improvement. Fixed locations for logistics coordination should have been established earlier, and the response teams were short on trained and knowledgeable staff, so personnel were far overtaxed. People were needed to take charge of crowd control, communication with the command center, and central supply. ${ }^{45}$

The influx of media representatives was an escalating problem. Although individuals on the ground tried to keep them roped off and allow access only to credentialed personnel, it was almost too late. Volunteers came in excess to the disaster site, but the greatest need for medically-trained volunteers was in the hospital units. ${ }^{46}$ The initial chaos was magnified by these volunteers and donations due to the lack of an authority structure and plan to organize them. Poor communication and the absence of a plan in the first place led to mal-distribution, and inventory control quickly became very overwhelming: "In fact, by early afternoon, it became increasingly apparent that donated goods would be a problem for the duration of the event. This represents one of the major deficiencies in the state and local planning effort. ${ }^{\circ 7}$ While there were excesses in some areas, there were shortages in others, but these were both preventable. ${ }^{48}$ Hospitals struggled from similar challenges. Pharmacy disaster carts were well-supplied but some of the hospital staff members were unfamiliar with medications and needed pharmacists to

${ }^{41}$ City of Oklahoma City Final Report—Alfred P. Murrah Federal Building Bombing, April 19, 1995 (Fire Protection Publications: Stillwater, OK,1996), 42.

42 Ibid.

${ }^{43}$ Ibid., 41.

${ }^{44}$ Ibid. 43.

${ }^{45}$ Ibid., 53.

${ }^{46}$ Anteau, Carlene M., and Linda A. Williams, 1998, "The Oklahoma City bombing," Nursing 28, no. 3: 52-55, Academic Search Premier, EBSCOhost (accessed May 8, 2018), 52.

${ }^{47}$ City of Oklahoma City Final Report—Alfred P. Murrah Federal Building Bombing, April 19, 1995 (Fire Protection Publications: Stillwater, OK,1996), 8.

${ }^{48}$ Anteau, Carlene M., and Linda A. Williams. 1998. "The Oklahoma City bombing." Nursing 28, no. 3: 52-55. Academic Search Premier, EBSCOhost (accessed May 8, 2018). 54. 
accompany them to treatment areas. ${ }^{49}$ Another management and logistical challenge was documenting patient care. ${ }^{50}$

\section{Victim and Family Support}

Significantly, there was no model in place to guide actors on the ground - at any level - on how to respond to and provide both short-term and long-term support to victims and their families. ${ }^{51}$ Ill-prepared to shoulder the emotional burden and provide stress management functions, those at the scene learned the difficult lesson that stress management must be recognized as a crucial component of emergency preparedness and included in the planning process. ${ }^{52}$ They must not only seek outside assistance early, but continue to deliver resources for long-term support to victims and families. Though nearly $\$ 50$ million dollars were donated to assist those affected within the first year, some individuals and families faced financial hardship because they may not have requested help or received all the funds they needed. ${ }^{53}$ When the major disaster declaration was later issued, the governor requested a Crisis Counseling program, which provided funding to local and state mental health authorities to help survivors affected by the disaster. ${ }^{54}$ An external Critical Incident Stress Management team came a few days later to help staff emotionally recover. Their goal was to prevent posttraumatic stress, yet this should have ideally been in operation the day of the event. Many employees were either hesitant to attend due to the stigma, or not provided the opportunity to attend given their other responsibilities. ${ }^{55}$ On whole, the response and recovery team leaders were delayed in their realization that other staff members, such as the maintenance and engineering staff, technicians, housekeepers, and others, were also suffering from stress reactions.

\section{Public Perception, Media, Information Dissemination}

One of the most significant problems at the broader, national level was in minimizing biases and prejudices when responding to the terrorist attack. In the immediate aftermath of the bombing, the perpetrator was assumed and speculated to be of Middle Eastern descent. As evidence of this belief, CBS Evening News reported that a government source stated the bombing had "Middle Eastern terrorism written all over it." 56 Therefore one of the main learning

${ }^{49}$ Ibid.

${ }^{50}$ Ibid., 55.

${ }^{51}$ U.S. Department of Justice, Office of Justice Programs, Office for Victims of Crime, 2000, "Responding to Terrorism Victims: Oklahoma City and Beyond," NCJ 183949, Available from: https://www.ovc.gov/pdftxt/NCJ183949.pdf.

52 Ibid.

${ }^{53}$ Oklahoma City National Memorial Museum, "Recovery: The Financial Impact of the Oklahoma City Bombing," 5, Available from: https://oklahomacitynationalmemorial.org/wpcontent/uploads/2018/03/OKCNM_Recovery-The-Financial-Impact.pdf.

${ }^{54} 42$ U.S.C. $\S 5183$.

${ }^{55}$ Anteau, Carlene M., and Linda A. Williams, 1998, "The Oklahoma City bombing," Nursing 28, no. 3: 52-55, Academic Search Premier, EBSCOhost (accessed May 8, 2018), 55.

${ }^{56}$ Rubin, Gabriel, 2008, "Balancing Fear: Why Counter-Terror Legislation was Blocked after the Oklahoma City and London Bombings," Conference Papers -- Midwestern Political 
lessons is that not only should we be cautious of implicit biases to avoid offending and marginalizing a particular group of citizens, but for news releases and media liaising, there should be a cadre of public information and public relations personnel that can support each level of government and agency to accommodate the massive demand for monitoring, documentation, and analysis. The division of power is important to respond effectively, yet unity is imperative in the aftermath of such a crisis.

\section{Relationship Between the Executive and Legislative Branches of Government}

The pressures of a "zero tolerance" mentality for terrorist attacks are strong for a President, and often lead to calls for enhanced national security measures - especially after a major incident. Even federal agencies are faced with intense pressure from the Senate to "stop it before it is too late, before it actually happens" because "terrorism as experienced in Oklahoma City or New York City has no place in America." ${ }^{" 57}$ However, there are numerous challenges at play. Terrorism is the only type of crime that the government is often expected to prevent wholesale, rather than expected to respond to and enforce justice after the fact. The Secret Service protects government officials, but is "hampered in its attempt to gather information by FBI's statutory limitations in domestic surveillance." 58 The Bureau of Alcohol, Tobacco, Firearms and Explosives is similarly at a disadvantage because of limitations in the existing law - it is difficult to carry out explosive enforcement in the realm of antiterrorism. ${ }^{59}$ Therefore the Oklahoma City bombing raised questions of whether the government possessed the necessary tools to continue to execute and improve upon its basic law enforcement functions in counterterrorism, or whether it needed an expanded legal framework to handle the new threats.

\section{Tensions Between Liberty and Security}

This debate exposed the fundamental tension between liberty and security - an issue often faced in homeland security within nations that value certain civil liberties such as privacy, freedom of expression, and the right to bear arms. President Bill Clinton's proposed counterterrorism legislation was blocked for over a year by the Republican Party because of concerns over the curtailing of civil liberties. ${ }^{60}$ The 1996 Antiterrorism Act would allow the FBI to open investigations to more freely gather information based on First Amendment activities that gave an indication of association with terrorist groups, and criminalize certain behavior designated as terrorist. Ultimately, compromise legislation was eventually passed (the

Science Association 1-38, Political Science Complete, EBSCOhost (accessed May 8, 2018), 23.

57 1996. Oklahoma City bombing: hearing before a subcommittee of the Committee on Appropriations, United States Senate, One Hundred Fourth Congress, first session: special hearing. n.p.: Washington: U.S. G.P.O.: For sale by the U.S. G.P.O., Supt. of Docs., Congressional Sales Office, 1996., 1996. USMA Library Catalog, EBSCOhost

${ }^{58}$ Ibid., 5. (accessed May 8, 2018). 45.

59 Ibid., 49.

${ }^{60}$ Cole, David and James X. Dempsey, Terrorism and the Constitution: Sacrificing Civil Liberties in the Name of National Security, (New York: The New Press 2006), pg. 125, See also Lewis, Neil A. "Clinton Plan Would Broaden FBI Powers," The New York Times, April 251995. 
Antiterrorism and Effective Death Penalty Act of 1996); however, this was not until a year later because the bill was stalled on the grounds of civil liberties and gun ownership rights. ${ }^{61}$ President Clinton, experiencing strong pressure to guarantee the safety of the American people and prevent another similar attack, felt the need to turn to executive "threat-shaping" as a strategy to build consensus. Despite playing to the public's fear, it did not come across as urgent enough at first and required a drawn-out negotiated process between the executive and legislative branches of government. ${ }^{62}$ Additionally, the U.S. Constitution guarantees the right to defense counsel if an individual cannot afford one. Therefore, Timothy McVeigh and Terry Nichols' trials were funded by American taxpayer dollars. Some have raised the question of whether it is right and just for the public to pay for the defense of terrorists to ensure due process for all. ${ }^{63}$

\section{How These Lessons Learned Impacted Homeland Security}

After experiencing this crisis, the state and federal levels of the homeland security enterprise made a range of noteworthy changes to increase both its preventive capacity as well as its emergency response mechanisms for future incidents. This indicates that tragic incidents provide the main impetus for reform to homeland security structures and processes.

The Oklahoma City bombing increased concern and awareness over the issue of domestic terrorism, which led many local and state governments to write and receive federal grants for domestic preparedness support. Within Oklahoma, there were several advancements made to enhance terrorism prevention and make emergency response programs more robust. The Department of Justice provided grants to the state, which purchased $\$ 7,383,000$ worth of additional security equipment from $1999-2002 .{ }^{64}$ The state received $\$ 30.3$ million total in federal funding for this purpose. ${ }^{65}$ Additionally, a 2004 statute established the Oklahoma Office of Homeland Security (OKOHS), which was designated as the State Administering Agency that would carry out all federal homeland security training, equipment funding and technical assistance. $^{66}$

At the national level, the government carried out a set of actions to enhance its ability to detect, prevent, and respond to terrorist attacks. In an effort to protect federal employees and their families, it strengthened security measures for federal facilities, banned daycare centers

${ }^{61}$ Rubin, Gabriel. 2008, "Balancing Fear: Why Counter-Terror Legislation was Blocked after the Oklahoma City and London Bombings," Conference Papers -- Midwestern Political Science Association 1-38, Political Science Complete, EBSCOhost (accessed May 8, 2018), 29.

62 Ibid., 24.

${ }^{63}$ Oklahoma City National Memorial Museum, "Recovery: The Financial Impact of the Oklahoma City Bombing," 5, Available from: https://oklahomacitynationalmemorial.org/wpcontent/uploads/2018/03/OKCNM_Recovery-The-Financial-Impact.pdf.

${ }^{64}$ Ibid., 4.

${ }^{65}$ Ibid., 1

${ }^{66}$ Ibid., 5. 
from federal buildings, and closed streets near the White House. ${ }^{67}$ The General Services Administration, the landlord for most federal agencies, created additional security requirements including blast-resistant glass, required buildings to be set back from the street, and determined that they should be structurally engineered to increase blast resistance and prevent floors from progressively collapsing. ${ }^{68}$ Additionally, several Presidential Directives were issued including the Anti-Terrorism and Effective Death Penalty Act. ${ }^{69}$ The FBI underwent a set of transformative changes that received executive endorsement and increased its capacity to respond to terrorist incidents and other national security crises, manage massive cross-jurisdictional cases, and handle a large volume of records. Notably, President Clinton designated the FBI as the lead agency to investigate terrorist attacks against Americans and expanded the bureau's authority to investigate terrorist attacks against U.S. persons overseas. The FBI opened its Counterterrorism Division, a new Strategic Information and Operations Center, and its Joint Terrorism Task Force. $^{70}$

\section{Key Takeaways and Implications}

The response and recovery missions performed during the Oklahoma City Bombing will and should always be considered a "total success." ${ }^{171}$ Yet, there are some key learning lessons for future crises, and an array of challenges this disaster exposes in the homeland security arena that are relevant for the U.S. and other republics.

It quickly became clear after the Oklahoma terrorist attack that America is no longer isolated from the reaction of political groups or radical individuals from either the extreme left or right, and perhaps being a federal employee is inherently a risk. ${ }^{72}$ Furthermore, after experiencing this crisis, various levels within the homeland security enterprise carried out change to increase both its preventive capacity as well as its emergency response mechanisms for future incidents, an indication that tragedy is often the clearest way to expose and motivate necessary reform of homeland security structures and processes.

${ }^{67}$ John F. Fox, "Impact of the Oklahoma City Bombing 20 Years Later," Newseum, April 17, 2015, Available from: http://www.newseum.org/2015/04/17/impact-of-the-oklahomacity-bombing-20-years-later/.

${ }^{68}$ Brian Naylor, "Oklahoma City Bombing: A ‘Wake-Up Call' For Government Security,” NPR, April 17, 2015, Accessed February 27, 2019, https://www.npr.org/sections/itsallpolitics/2015/04/17/400362277/oklahoma-citybombing-a-wake-up-call-for-government-security.

${ }^{69}$ John F. Fox, "Impact of the Oklahoma City Bombing 20 Years Later," Newseum. April 17, 2015, Available from: http://www.newseum.org/2015/04/17/impact-of-the-oklahomacity-bombing-20-years-later/.

${ }^{70}$ Ibid.

${ }^{71}$ City of Oklahoma City Final Report—Alfred P. Murrah Federal Building Bombing, April 19, 1995 (Fire Protection Publications: Stillwater, OK,1996), 34.

72 1996. Oklahoma City bombing: hearing before a subcommittee of the Committee on Appropriations, United States Senate, One Hundred Fourth Congress, first session: special hearing. n.p.: Washington: U.S. G.P.O.: For sale by the U.S. G.P.O., Supt. of Docs., Congressional Sales Office, 1996., 1996. USMA Library Catalog, EBSCOhost (accessed May 8, 2018). 37. 
Within republics, executive leadership will likely feel pressure to do all they can to prevent another security incident and may therefore aim to enact even stronger measures to protect the nation. The balance between liberty and security is difficult but important - policy legislation must maintain a "delicate balance between freedom and order.",73

Regarding media, information dissemination, and public perception, one of the most significant learning lessons from this case is that not only should leaders be cautious of implicit biases and assumptions to avoid offending and marginalizing a particular subset of their population, but for news releases and media liaising, there should be a cadre of public information and public relations personnel that can support each level of government and each agency to accommodate the massive demand for monitoring, documentation, and analysis in the aftermath of the crisis. Again, unity is imperative.

In its division of responsibilities and authorities between the national, state, local, and private sector leaders and entities, federalism presents unique challenges. The wide spread of departments, agencies, actors, and stakeholders involved in the homeland security enterprise generates a degree of ambiguity and tension when enforcing homeland security efforts, even when a clear legal framework and healthy supply of resources exists. The local, state, and federal governments each have different scopes and concerns that are most pressing to them and politically salient. Communication between the levels of government is crucial to build shared awareness of threats the homeland faces, and also allows for the sharing of best practices, promotion of common standards, and open dialogue to continually assess and manage risk at all levels. Second, coordination is imperative to mitigate the damage and debilitation caused by crises, leverage resources and assets across the levels of government, and provide leadership and clear direction in the event of a crisis or attack. Operationally, structured, networked relationships work best when all functions are well-understood, and each level and agency is familiar with their own role and interactions with others.

Consequently, integrated training and partnerships between all levels of emergency management are vital to effectively respond to emergencies. State and local plans must be able to incorporate search and rescue response forces working in and around a crime scene that must be investigated rapidly; state and local plans should mirror and nest within the Federal and Regional Response Plans with additional emergency support functions added to fit the state and local situation. There must be a logistics plan to contain overwhelming crowds of volunteers and donations that may arrive immediately following the disaster. Psychological and emotional support must be included in the plan, as well as long-term support for victims and families.

In summary, leadership, partnerships, and teamwork matter - at all levels.

${ }^{73}$ Helen Dewar, "Clinton to Sign Terrorism Bill Depite Lack of Enforcement Provisions, Aid Says,” The Washington Post, 19 April 1996. 


\section{Bibliography}

Anteau, Carlene M., and Linda A. Williams. 1998. "The Oklahoma City bombing." Nursing 28, no. 3: 52-55. Academic Search Premier, EBSCOhost (accessed May 8, 2018).

Burkett, Jeffrey W. "Command and Control of Military Forces in the Homeland." Joint Force Quarterly 51, (4 ${ }^{\text {th }}$ Quarter 2008): 132.

City of Oklahoma City Final Report-Alfred P. Murrah Federal Building Bombing, April 19, 1995 (Fire Protection Publications: Stillwater, OK,1996) http://www.murderpedia.org/male.M/images/m/mcveigh/docs/okcfr_TOC.pdf

Cole, David and James X. Dempsey. Terrorism and the Constitution: Sacrificing Civil Liberties in the Name of National Security. (New York: The New Press 2006).

CRS Report R43560, Deployable Federal Assets Supporting Domestic Disaster Response Operations: Summary and Considerations for Congress, coordinated by Jared T. Brown.

Dewar, Helen. "Clinton to Sign Terrorism Bill Depite Lack of Enforcement Provisions, Aid Says." The Washington Post. 19 April 1996.

FEMA, Emergency Declaration, EM 3115. Federal Register Volume 60, Number 88. May 8, 1995. https://www.gpo.gov/fdsys/pkg/FR-1995-05-08/html/95-11243.htm.

FEMA. "Incident Command System Resources." U.S. Department of Homeland Security. Last modified June 26, 2018. Accessed February 27, 2019. https://www.fema.gov/incidentcommand-system-resources.

Fox, John F. "Impact of the Oklahoma City Bombing 20 Years Later." Newseum. April 17, 2015. Available from: http://www.newseum.org/2015/04/17/impact-of-the-oklahoma-citybombing-20-years-later/

Harris, John F. "Clinton Criticizes Congress for Delay on Post-Bombing Anti-Terrorism Bill," The Washington Post, 1 June 1995.

Homeland Security and Emergency Management. "About the SEOC." Minnesota Department of Public Safety. Last modified 2019. Accessed February 27, 2019. https://dps.mn.gov/divisions/hsem/seoc/Pages/about-seoc.aspx.

Lewis, Neil A. "Clinton Plan Would Broaden FBI Powers.” The New York Times. April 251995.

Lindsay, Bruce R. 2017. "Oklahoma City Bombing." Congressional Research Service: Report 12-13. International Security \& Counter Terrorism Reference Center, EBSCOhost (accessed May 8, 2018).

Manzi, Catherine, Powers, Michael J., and Zetterlund, Kristina. 2002. "Critical Information Flows in the Alfred P. Murrah Building Bombing: A Case Study." CBACI. Terrorism 
Studies Series, Special Report 3.

https://www.ncjrs.gov/pdffiles1/Digitization/194411NCJRS.pdf.

Moss, Mitchell \& Schellhamer, Charles \& A. Berman, David. (2009). The Stafford Act and Priorities for Reform. Journal of Homeland Security and Emergency Management - J HOMEL SECUR EMERG MANAG. 6. 10.2202/1547-7355.1538.

Naylor, Brian. “Oklahoma City Bombing: A ‘Wake-Up Call' For Government Security.” NPR. April 17, 2015. Accessed February 27, 2019. https://www.npr.org/sections/itsallpolitics/2015/04/17/400362277/oklahoma-citybombing-a-wake-up-call-for-government-security.

O'Cleary, Conor. "Clinton calls for tough new laws on terrorism." The Irish Times. April 24, 1995.

Oklahoma City National Memorial Museum. "Recovery: The Financial Impact of the Oklahoma City Bombing." Available from: https://oklahomacitynationalmemorial.org/wpcontent/uploads/2018/03/OKCNM_Recovery-The-Financial-Impact.pdf

Oklahoma National Guard. “About.” Guard Advocacy Program. Accessed on February 27, 2019. https://ok.ng.mil/pages/about.aspx

Roberts, Patrick. "FEMA After Katrina." Hoover Institution Policy Review \#137. Online. http://www.policyreview.org/137/roberts.html.

Rubin, Gabriel. 2008. "Balancing Fear: Why Counter-Terror Legislation was Blocked after the Oklahoma City and London Bombings." Conference Papers -- Midwestern Political Science Association 1-38. Political Science Complete, EBSCOhost (accessed May 8 , 2018).

Smith, Mike R. "Guardmembers Remember Oklahoma City Bombing." U.S. Army. April 19, 2010. Accessed on February 27, 2019.

https://www.army.mil/article/37587/guardmembers_remember_oklahoma_city_bombing

U.S. Congressional Research Service. 2019. "Stafford Act Assistance and Acts of Terrorism." R44801. Available from: https://fas.org/sgp/crs/homesec/R44801.pdf

U.S. Department of Justice, Office of Justice Programs, Office for Victims of Crime. 2000. "Responding to Terrorism Victims: Oklahoma City and Beyond." NCJ 183949. Available from: https://www.ovc.gov/pdftxt/NCJ183949.pdf

Winthrop, Jim. "Oklahoma City Bombing: Immediate Response Authority and Other Military Assistance to Civil Authority." National Criminal Justice (1997): Abstract. https://s3-uswest-2.amazonaws.com/webcitation/f40c023b564c767e7ab576332e3425c6ab89a786

Witt, James Lee and James Morgan, Stronger in the Broken Places (New York: Times Books), p. 109. 
1996. Oklahoma City bombing: hearing before a subcommittee of the Committee on Appropriations, United States Senate, One Hundred Fourth Congress, first session: special hearing. n.p.: Washington: U.S. G.P.O.: For sale by the U.S. G.P.O., Supt. of Docs., Congressional Sales Office, 1996., 1996. USMA Library Catalog, EBSCOhost (accessed May 8, 2018).

42 U.S.C. $§ 5183$. 